J. Lake Sci. (湖泊科学), 2015, 27(2): 266-274

http: //www.jlakes. org. E-mail : jlakes@niglas.ac.cn

(c) 2015 by Journal of Lake Sciences

\title{
鄱阳湖流域大型湖库水生生态环境变化及驱动力分析一以柘林湖 为例
}

刘慧丽 ${ }^{1}$, 戴国飞 ${ }^{1,2}$, 张 伟 ${ }^{1,2}$, 廖 兵 $^{1}$

( 1 : 江西省环境保护科学研究院, 南昌 330039 )

( 2 : 江西省水利科学研究院鄱阳湖水资源与环境重点实验室,南昌 330029)

摘 要: 鄱阳湖流域内湖库资源众多, 柘林湖作为鄱阳湖最大的人湖湖库, 是鄱阳湖流域内最大的调节湖库, 对鄱阳湖人 湖径流有一定的影响, 在鄱阳湖的人湖流量中占重要地位. 本文以鄱阳湖流域内纳人水质良好湖泊的柘林湖为例, 通过 对柘林湖的形成及湖泊水系生态环境演变进行探讨, 分析近 30 年来该湖水生生态环境的变化及其关键驱动力因子. 综合 研究表明: 柘林湖水生生物多样性有下降趋势, 水质有先变差后改善的趋势, 其变化的驱动力主要是流域内人口数量增 加、城镇化工业化进程加快、入湖污染负荷逐年增长、滨湖区生态安全屏障受人为破坏以及资源开发不合理等. 只有处理 好“人湖”和谐、“三次飞跃” 和“四大转变”, 并采取科学合理的措施进行集成研究和综合治理, 才能行之有效地改善柘林 湖水生生态环境,并发挥其应有的生态效应,从而保障鄱阳湖人湖“一湖清水”.

关键词: 鄱阳湖;柘林湖;水生生态环境;驱动力分析

\section{Analysis of the water ecological environment changes of the large lakes and driving fac- tors in Lake Poyang basin: A case study of Lake Zhelin}

\author{
LIU Huili ${ }^{1}$, DAI Guofei ${ }^{1,2}$, ZHANG Wei ${ }^{1,2} \&$ LIAO Bing ${ }^{1}$ \\ (1: Jiangxi Academy of Environmental Science, Nanchang 330039, P. R. China)
}

(2: Jiangxi Provincial Key Laboratory of Water Resources and Environment of Poyang Lake, Jiangxi Institute of Water Sciences, Nanchang 330029, P. R. China)

Abstract: There are numerous lakes and reservoirs in the Lake Poyang basin. As the largest inflowing reservoir, Lake Zhelin serves as the largest regulating reservoir in the Lake Poyang basin. Lake Zhelin has a certain influence on the runoff into Lake Poyang. It can provide water flow to Lake Poyang during dry seasons and reduce the water flow during wet seasons. This paper focused on Lake Zhelin by discussing its formation and its water ecological environment changes. Then, Lake Zhelin's water environment changes in the past 30 years and the key driving factors of environmental evolution were analyzed. Results showed that Lake Zhelin's aquatic biodiversity decreased and water environment deteriorated but exhibited a recovery. The driving factors were the growing population in the watershed, leading to a higher pollution loading into the lake in recent years. This situation became worse due to further man-made destruction on the lake district ecological security barrier, unsustainable use and over exploitation of resources. Only by resolving the relationship between people and lake and taking reasonable measures to carry out integration research and comprehensive treatment, Lake Zhelin's water environment can be improved effectively and play its role in protecting Lake Poyang. Keywords: Lake Poyang; Lake Zhelin; water ecological environment; analysis of driving factors

湖泊水库是人类当前及未来发展所必需的一种重要的战略资源, 发挥着正常的供水、灌溉、渔业、景观、 洪水调蓄和生物多样性维持等多重生态功能 ${ }^{[1]}$, 在人民生产生活中扮演着越来越重要的角色. 而湖库生态 安全则是支撑和保障湖库流域社会经济环境持续发展的重要途径, 1990s 以来, 随着污染排放、生态破坏、过 度侵占湖泊资源等一系列人类干扰活动的加剧, 湖泊水库富营养化等问题凸显, 湖库生态安全问题越来越

* 国家良好湖泊生态环境保护专项和江西环保科技项目 ( JXHBKJ201214) 联合资助. 2014-04-14 收稿; 2014-10-10 收修改稿. 刘慧丽 $(1981 ）$, 女, 硕士, 高级工程师; E-mail : qinshiyuelhl@ 126. com. 
受到人们的重视 ${ }^{[2-3]}$. “九五” 至“十一五” 期间, 国家投人巨资治理 “三江”、“三湖”, 但成效不是很明显. “十 二五” 期间国家调整工作思路, 为避免走 “先污染、后治理” 的老路, 把目光投向气候、环境、地质、生态各异的 全国五大湖区 (东部平原湖区、蒙新高原湖区、云贵高原湖区、青藏高原湖区和东北平原一山地湖区), 并编制 了《良好湖泊生态环境保护规划(2011-2020)》,于 2013 年 12 月 18 日经国务院常务会议通过, 纳人规划的 良好湖泊共 365 个, 水面面积共计 $7.37 \times 10^{4} \mathrm{~km}^{2[27]}$. 此外, 财政部、环保部联合印发《江河湖泊生态环境保护 项目资金管理办法》 (财建 [2013]788 号), 实施水质良好湖泊生态环境保护专项 (2013 年底将地下水、地表 水其他专项并人设立江河湖泊生态环境保护专项), 于 $2011 、 2012 、 2013 、 2014$ 年分别在 9、25、45 和 64 个湖 泊连续开展了 4 批江河湖泊生态环境保护专项工作, 专项资金支持额度也从 9 亿、15 亿、16 亿增至 95 亿, 带 动地方资金约 200 亿元. 良好湖泊保护不同于我们长期进行的污染治理思路, 而是按照 “保护优先、预防为 主、自然修复” 的理念构建良好湖泊生态安全格局, 鼓励探索实施 “一湖一策” 的生态环境保护方式, 以增量 (优质湖泊) 来带动和优化存量 (非优质湖泊) 的源头保护思维, 与过去的先污染后治理的末端控制理念有 了根本性变化 ${ }^{[4]}$.

鄱阳湖是中国东部平原湖区中典型的通江湖泊 ${ }^{[5]}$, 流域内湖库资源众多, 常年水面面积在 $1 \mathrm{~km}^{2}$ 以上的 天然湖泊 86 个, 水面总面积 $3802 \mathrm{~km}^{2}$; 其中面积为 $1000 \mathrm{~km}^{2}$ 以上的湖泊 1 个, 即鄱阳湖 (星子水位黄海高程 为 $14.68 \mathrm{~m}$ 时, 水面总面积为 $2978 \mathrm{~km}^{2}$, 最大水深为 $29.19 \mathrm{~m}$, 平均水深为 $5.1 \mathrm{~m}$, 蓄水量为 $149.6 \times 10^{8} \mathrm{~m}^{3}$. 当星子水位黄海高程为 $20.66 \mathrm{~m}$ 时, 水面总面积为 $5156 \mathrm{~km}^{2}$ ) ; 面积为 $100 \mathrm{~km}^{2}$ 以上的湖泊 2 个, 水面总面积 $3142 \mathrm{~km}^{2}$; 面积为 $10 \mathrm{~km}^{2}$ 以上的湖泊 15 个, 水面总面积 $3593 \mathrm{~km}^{2}$; 水库 10819 座, 总库容 $320.81 \times 10^{8} \mathrm{~m}^{3}$. 其 中大型水库 30 座, 中型水库 263 座, 小型水库 10526 座, 大型水库库容占全部水库的 $59.2 \%{ }^{[6]}$.

柘林湖 (水域面积 $308 \mathrm{~km}^{2}$ ) 是中国最大淡水湖鄱阳湖的重要前置库之一, 其流量调度对鄱阳湖人湖径 流有一定影响, 能在枯水期补充鄱阳湖流量, 在丰水期起流量削峰的作用, 为鄱阳湖输送一湖清水, 且为鄱 阳湖西部地区 (修河流域) 生物多样性最丰富的地区, 生态地位突出. 柘林湖现状水质类别和水质目标均为 II III类, 属于良好湖泊范畴, 既是九江市武宁县、德安县、共青城市及周边沿湖百万居民的主要水源地, 又 是流域城乡生活污水及工业废水等的主要纳污水体, 主要人湖河流有修河上游、罗坪水、烟港水、瓜源水、沙 田水和罗溪水等 13 条.

柘林湖作为江西省良好湖泊的代表, 被列入第二批江河湖泊生态环境保护专项. 由于之前对柘林湖流 域缺乏系统深人的研究, 其水生生态情况、营养盐输人、形态特征及相关污染控制等研究相对较少,2011 年 开始着手对流域生态环境进行问题诊断, 并开展水生生态变化趋势及驱动力分析研究. 本文在分析鄱阳湖 流域内大型湖库水生生态环境变化趋势的基础上, 对柘林湖的形成及湖泊水系生态环境演变进行探讨, 分 析近 30 年来特别是 2000 年以来该湖水生生态环境的变化趋势及驱动因子. 此研究对全国其他大型深水湖 库相关研究具有参考意义,也为下一步实施湖泊生态环境保护工程规划和科学决策提供科学依据.

\section{1 材料与方法}

\section{1 采样点设置}

2012 年 8 月至 2013 年 7 月开展了为期一年的基线调查 (主要包括水质、浮游植物、浮游动物、底栖动 物、水生植物、鱼类等), 水质监测每月 1 次, 浮游植物、浮游动物、底栖动物为每季度 1 次, 水生植物和鱼类 为半年 1 次. 并依据有关技术指南 ${ }^{[28]}$ 进行调查. 监测点位如图 1 所示.

1) 水质监测点位: 湖区例行监测点位 4 个,2012 年补充 2 个; 人湖河流例行监测点位 2 个,2012 年补充 16 个. 水质监测时间为 2000 年 1 月到 2013 年 11 月,2000 年之前是水质定性评价结果, 2013 年 8 月之后为 水质例行监测结果 (监测频率为两月 1 次).

2) 浮游植物、浮游动物、底栖动物监测点位 16 个,监测时间为 2012 年 8 月到 2013 年 7 月.

3 ) 水生植物和鱼类调查监测范围为全湖区,监测时间为 2012 年 8 月到 2013 年 7 月.

\section{2 样品采集、处理及分析}

水质监测指标包括《地表水环境质量标准》(GB3838-2002) 中的常规指标及湖库需重点关注的指标, 如: 溶解氧 $(\mathrm{DO})$ 、总氮 $(\mathrm{TN})$ 、总磷 $(\mathrm{TP})$ 、高锰酸盐指数 $\left(\mathrm{COD}_{\mathrm{Mn}}\right)$ 、铵态氮 $\left(\mathrm{NH}_{4}^{+}-\mathrm{N}\right)$ 、透明度 $(\mathrm{SD})$ 、悬浮质 

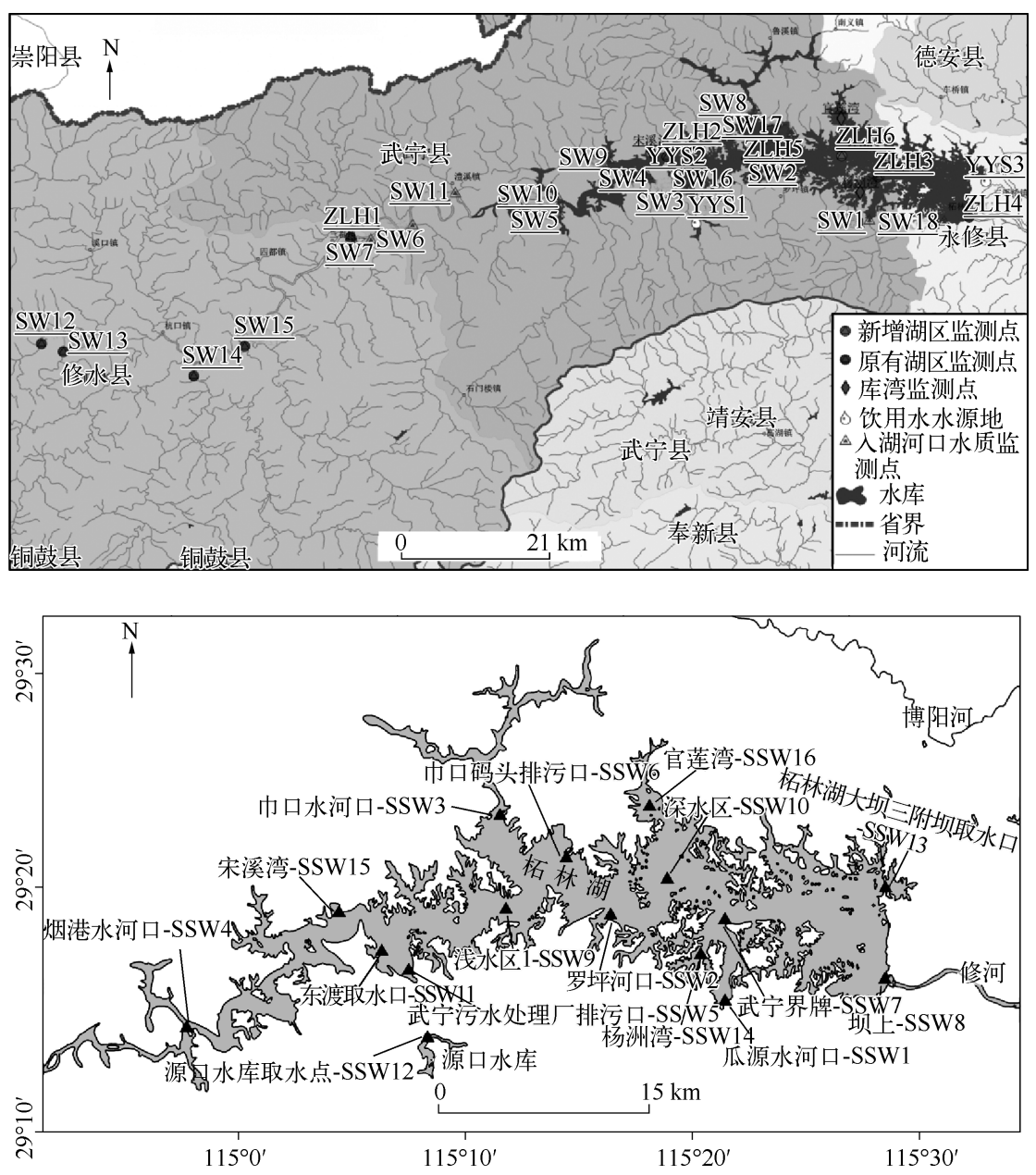

图 1 柘林湖水质 ( a ) 和浮游植物、浮游动物、底栖动物 (b) 监测点位空间分布 (SW1 瓜源水、SW2 罗坪水、SW3 源口水、SW4 沙田水、SW5 罗溪水、SW6 清江水、 SW7 洋湖港水、SW8 巾口水、SW9 西渡港、SW10 烟港水、SW11 大源水、SW12 渣津 水河口、SW13 东津桥、SW14 武宁水河口、SW15 修水县城、SW16 武宁县污水处理 厂人湖排污口、SW17 巾口码头、SW18 司马码头、ZLH1 修水县三都( 湖区进水 区) 、ZLH2 武宁渡口（湖区岸边区）、ZLH3 武宁界牌（湖区湖心区）、ZLH4 坝上 (湖区出水区)、ZLH5 湖区浅水区、ZLH6 湖区深水区、YYS1 源口水库、YYS2 柘林 湖东渡取水口、YYS3 柘林大坝三附坝)

Fig. 1 Water quality(a) and phytoplankton, zooplankton, zoobenthos(b) distribution of Lake Zhelin routine monitoring sites

(SS)、叶绿素 a(Chl. a) 等,各指标均采用国标法进行采样、测定和评价.

现场测定水温和透明度, 采集表层水 $(0 \sim 0.5 \mathrm{~m})$ 与底层水( 距底部 $0 \sim 0.5 \mathrm{~m})$ 混合水样用于理化指 标测定; 同时采集1 L水样用鲁哥试剂 (浓度约 $1.5 \%$ ) 固定浓缩后, 定容至 $30 \mathrm{ml}$ 用于浮游植物定量测 定; 采 $20 \mathrm{~L}$ 水样经浮游动物网浓缩到 $30 \mathrm{ml}$ 用于浮游动物鉴定; 部分蓝藻较多区域还对溶解性微囊藻毒 素进行了测定: 原水用 $0.45 \mu \mathrm{m}$ 滤膜过滤后于 $-20^{\circ} \mathrm{C}$ 保存, $72 \mathrm{~h}$ 内用 ELISA 法直接测定, 具体操作参 考文献 $[7-8]$.

浮游生物计数鉴定采用血球计数板法, 鉴定方法参考《中国淡水藻类: 系统、分类及生态》 ${ }^{[9]}$ 和《淡 
水微型生物图谱 $\rangle^{[10]}$. 优势种由 Menaughton 指数 $Y$ 确定, $Y=\left(n_{i} / N\right) f_{i}, n_{i}$ 为第 $i$ 种藻类的细胞数, $N$ 为 样品中所有藻类的总细胞数, $f_{i}$ 为第 $i$ 种藻类在各样点出现的频率, 取优势度指数 $Y>0.02$ 的藻类定 为优势种 ${ }^{[11]}$.

底栖动物采用 $1 / 16 \mathrm{~m}^{2}$ 彼得森采泥器或 $0.09 \mathrm{~m}^{2}$ 索伯网,多处采集, 综合计算的方式; 采用 $\mathrm{D}$ 形手抄网等 工具在岸边草丛和大石块底质表面进行定性采集, 折合成 $1 \sim 12 \mathrm{~m}^{2}$ 不等的采样面积. 现场将底栖动物样本 活体挑出, 放人样本瓶, 用 $10 \%$ 福尔马林溶液固定和保存, 在实验室分类、鉴定和计数, 用千分之一分析天平 称量标本重量, 然后折算成每平方米的密度和生物量. 使用 Wright 生物指数 (每平方米颤蚓科的数量) 对柘 林湖进行水质评价.

采用水生植物采集器 (镰式采草器) 对河内和湖库内分布的水生植物进行采样, 每样点采集面积 $0.4 \mathrm{~m}^{2}$,鉴定水生植物种类, 记录其群落组成特征,并称量其鲜重, 计量群落生物量.

根据鱼类区系研究方法, 对调查范围内的鱼类资源进行调查统计. 一般采用电捕捞、刺网 ( 1 指 4 指网 目不等)等捕捞方式, 湖库采用大船围捕的方式; 再结合在渔船集中停靠码头处、集贸市场调查统计、渔民询 问统计和历史资料收集等. 取样时随机选择优势鱼类每种 20 尾进行详细测量 (体长、全长、体重等). 鱼类鉴 定依据文献 $[29]$. 取自一个采样点的样品鱼, 按鱼类种类统计其尾数和总重量, 同时统计总渔获量.

\section{2 柘林湖流域概况}

\section{1 柘林湖的形成及演变过程}

柘林湖于 1958 年 7 月 1 日正式动工兴建, 历经 3 个时期至 1983 年 6 月全面竣工, 因位于亚洲第一大水 电土坝拦河工程所在地一一柘林镇而得名. 自柘林湖建成蓄水后, 汇水区域面积 $9340 \mathrm{~km}^{2}$, 占修河全流域面 积 $\left(14797 \mathrm{~km}^{2}\right)$ 的 $63.5 \%$, 范围涉及武宁县、修水县和永修县, 湖泊面积 $308 \mathrm{~km}^{2}$, 南北宽 $15.53 \mathrm{~km}$, 东西长 $44 \mathrm{~km}$, 湖区平均水深 $18.59 \mathrm{~m}$, 最大水深 $45 \mathrm{~m}$, 多年平均流量 $255 \mathrm{~m}^{3} / \mathrm{s}$, 多年平均年径流量 $80.6 \times 10^{8} \mathrm{~m}^{3}$. 水 库正常蓄水位 $65.0 \mathrm{~m}$, 相应库容 $50.17 \times 10^{8} \mathrm{~m}^{3}$; 设计洪水位 $70.13 \mathrm{~m}$, 相应库容 $67.71 \times 10^{8} \mathrm{~m}^{3}$; 校核洪水位 $73.01 \mathrm{~m}$, 相应库容 $79.2 \times 10^{8} \mathrm{~m}^{3}$ (总库容), 其中兴利库容 $34.7 \times 10^{8} \mathrm{~m}^{3}$, 调洪库容 $32 \times 10^{8} \mathrm{~m}^{3}$. 库容系数为 $42.7 \%$, 径流利用系数为 $93.4 \%$, 补给系数为 32.06 . 柘林湖湖区风景秀丽, 素有江西 “千岛湖” 之称, 被誉为 “庐山西海”, 是 $4 \mathrm{~A}$ 级国家风景名胜区、江西省最大的一座秀美壮观的人工湖、省级地质公园 ${ }^{[12]}$. 水库建成 30 年, 成为集防洪、发电、灌溉、供水、旅游等功能为一体的综合性水库, 发育成熟后受流域影响更显著, 具有 空间异质性与季节变动性,其发展和生态系统的演替受到人类活动的严重影响 ${ }^{[13]}$.

\section{2 社会经济发展}

2. 2.1 历年人口变化趋势 2013 年, 柘林湖流域人口 123.92 万(图 2a), 其中农业人口 105.07 万, 占流域人 口总数的 $84.88 \%$, 非农业人口 18.72 万, 占流域人口总数的 $15.12 \%$, 城镇化率为 $14.3 \%$, 是全省平均水平的 三分之一; 人口密度为 153 人 $/ \mathrm{km}^{2}$, 比 $1980 \mathrm{~s}$ 年 $\left(132\right.$ 人 $\left./ \mathrm{km}^{2}\right)$ 增加了 $15.91 \%$, 远低于九江市 $\left(253\right.$ 人/ $\left.\mathrm{km}^{2}\right)$ 和 全省 $\left(269\right.$ 人 $/ \mathrm{km}^{2}$ ), 从 $1980 \mathrm{~s}$ 至 2013 年全流域人口平均自然增长率约 $8 \%$. 流域人口分布与地形关系密切, 而流域以中山、低山和丘陵地貌为主, 总体呈现山区人口密度较小、平原地区人口密度较大、丘陵地区介于 两者之间的特征 ${ }^{[14]}$.

2.2 .2 历年经济变化趋势 2013 年, 柘林湖流域地区生产总值 190.57 亿元 ${ }^{[14]}$ (当年价, 下同) (图 2b), 占全 省地区生产总值的 $1.19 \%$, 人均生产总值 1.15 万元, 是全省平均水平的 $44.0 \%$, 是全国平均水平的 $32.7 \%$, 流 域第一产业生产总值为 29.12 亿元, 第二产业生产总值为 98.40 亿元, 第三产业生产总值为 63.04 亿元, 三次 产业结构比例为 $15.28 \% 、 51.64 \% 、 33.08 \%$, 三次产业结构由 $1980 \mathrm{~s}$ 年的 “一、三、二 转变为 “二、三、一”结构模 式, 虽然年均增长率为 $15.61 \%$, 区域经济仍比较落后, 流域范围内人均生产总值不均衡. 流域内的修水县 (国 家级贫困县) 和武宁县经济发展长期滞后, 至今尚有 26 万人未能脱贫, 占两县总人口比率高达 $21.6 \%$.

柘林湖流域经济以农业、林业、旅游业、矿业为主. 其中修水县以矿产、陶瓷、建材、缫丝、水电、食品等为 主导产业; 武宁县以矿产、节能电器和绿色能源为支柱产业; 庐山西海管委会以发展生态旅游业为主, 2006 年开始大力发展旅游业, 至今, 年接待游客自 53.27 万人增至 122.31 万人, 游客数量呈现增长趋势, 旅游年 总收人也从 7.2 亿元增长至 13 亿元. 


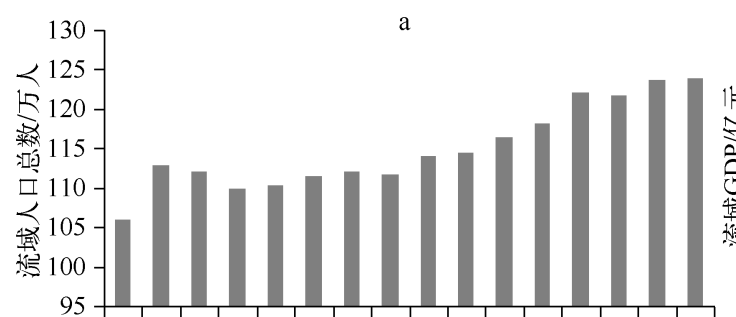

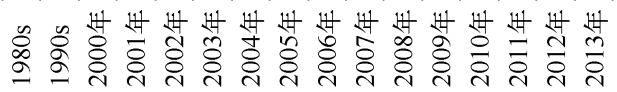

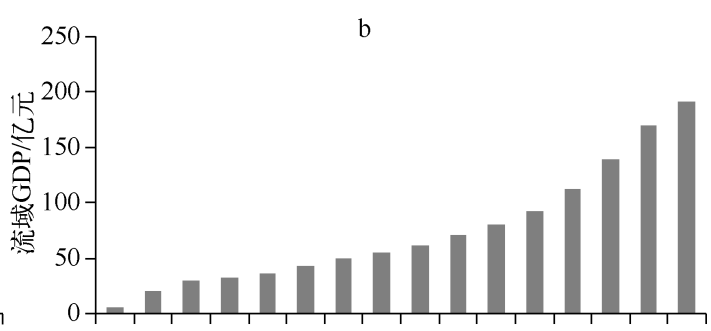

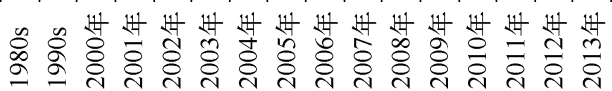

图 2 柘林湖流域人口总数 $(a)$ 和 $\operatorname{GDP}(\mathrm{b})$ 增长趋势

Fig. 2 Population growth(a) and GDP(b) trends of Lake Zhelin basin

\section{3 近 30 年柘林湖水环境变化}

\section{1 湖区水质现状及历年变化趋势}

$1980 \mathrm{~s}-1990 \mathrm{~s}$, 由水质定性评价结果可知, 柘林湖总体水质为 I 类, 上游来水和滨湖水质稳定在 II 类, 清 洁水体指示物种——桃花水母在湖中大规模出现. 自 1990s 末以来的近 10 年, 受上游来水和滨湖区开发的 影响, 特别是对 2000-2013 年柘林湖 4 个例行监测点位 (ZLH1 ZLH4) 年平均监测数据进行评价分析表 明 ${ }^{[15]}$, 除 TP 和 TN 在 III 类水平, 其它指标都能维持在 II 类水平. 从近 13 年以来的 $\mathrm{COD}_{\mathrm{Mn}}$ 数据来看, 总体保持 在 II 类, 2004 年以后由 I 类下降至 II 类, 2013 年稳定在 II 类; 从 $\mathrm{NH}_{4}^{+}-\mathrm{N}$ 数据来看,一直稳定在 I 、 II 类; 从 $\mathrm{TN}$ 数据来看, 2004 年以后呈下降趋势, 2006 年呈上升趋势, 2013 年又呈下降趋势, 目前维持稳定在 III 类水 平; 从 $\mathrm{TP}$ 数据来看, 稳定在 III 类水平.

此外, 从空间分布来看, 东部湖区 (出水区) 水质优于西部湖区 (进水区) 水质. TP 浓度大小为:ZLH4 $<$ ZLH3 < ZLH2 <ZLH1; TN 浓度为:ZLH4 <ZLH3 < ZLH1 < ZLH2. 坝上 (出水区) 水质最好, 达到 II 类. 主要原 因为柘林湖流域地势西高东低, 上游修河来水从西部人湖, 且修水和武宁县城处在西部和西南部, 人湖河流 污染物浓度由西至东逐渐衰减, 因此目前总体上湖区水质稳定在 III类, 但 $\mathrm{COD}_{\mathrm{Mn}} 、 \mathrm{NH}_{4}^{+}-\mathrm{N}$ 和 TP 浓度近几年 呈下降趋势 (图 3).

综上所述, 从 1980s 至 2013 年湖区水质变化趋势从 I 类至 II 类、 II 类至 III 类, 最终稳中又有变好的趋 势. 影响水质类别的制约性因素为 TP 和 TN, 氮、磷浓度的升高势必导致藻类增殖和水华暴发风险增加, 影 响供水安全, 因此需重点加强柘林湖水环境及水生生态保护.

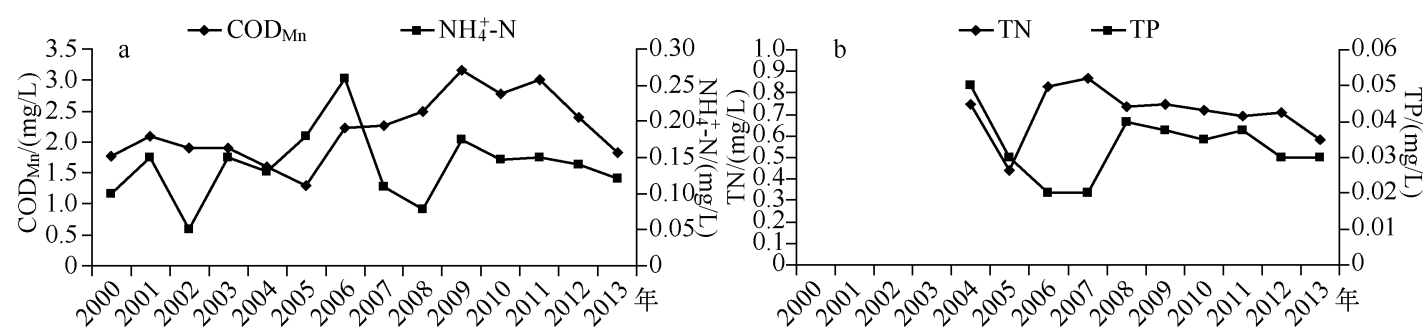

图 $32000-2013$ 年柘林湖 $\mathrm{COD}_{\mathrm{Mn}}$ 和 $\mathrm{NH}_{4}^{+}-\mathrm{N}(\mathrm{a}) 、 \mathrm{TN}$ 和 $\mathrm{TP}(\mathrm{b})$ 的变化趋势

Fig. 3 Potassium permanganate index and ammonia nitrogen(a), total nitrogen and total phosphorus (b) trends in Lake Zhelin from 2000 to 2013

\section{2 湖区营养化状态及历年变化趋势}

2008 年之前由于缺少透明度等监测指标, 不能进行营养状态评价, 但是相关文献 ${ }^{[30]}$ 显示, 1990s 柘林湖 透明度高达 $11 \mathrm{~m}$ 以上, 定性评价为贫营养型湖泊;2008-2013 年间柘林湖富营养化状态评分值在 33 47 
之间(图 4), 透明度由 $1 \mathrm{~m}$ 以上又改善至 $4 \mathrm{~m}$ 左右, 总体维持在中营养水平. ZLH1 和 ZLH2 点位的评分值最高, 营养化程度最重; ZLH4 和 ZLH3 点位评分值最低, 营养化程度最轻; 湖心 区和出水区水体营养化程度维持稳定并有转 好的趋势.

\section{3 入湖河流水质现状及历年变化趋势}

人湖支流例行监测断面仅设置在修河干 流, 2000-2007 年修河设置 2 个点位, 2008 年 后设置了 4 个点位, 2012 年设置了 18 个点位 (SW1 SW18). 由近 12 年来的监测结果可 知, 2007 年之前 SW12 和 SW15 断面在 2004

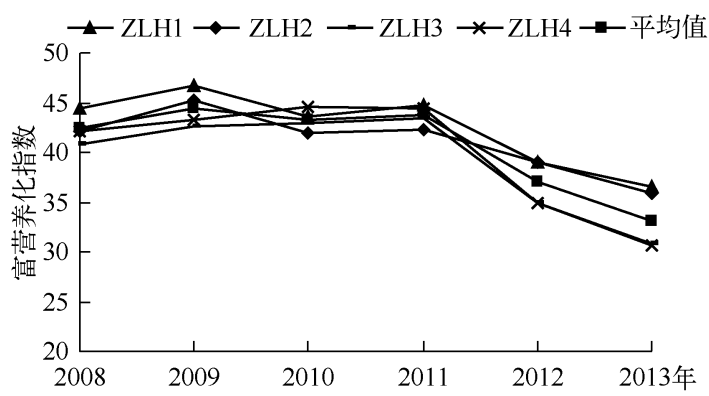

图 4 2008-2013 年柘林湖湖区富营养化指数变化趋势 Fig. 4 Eutrophication index of Lake Zhelin from 2008 to 2013

年和 2006 年 TN 有超 IV 类和劣 V 类现象, 2008 年之后 TN 达 III 类, 若 TN 不参与评价, 总体来说近年来人湖 河流水质有所改善, 达到地表水环境质量标准 (GB3838-2002) 中 III 类标准, 2012 年人湖河口每个断面年均 值全都达到地表水环境质量标准 $(\mathrm{GB} 3838-2002)$ 中的 II 类水质标准, 若 TN 参与河流评价, 则除 SW7、 SW12、SW13 II 类以外, 其它人湖河流均达 III 类. 由于 TP 在总体上达到 II 类, 对 18 个点位进行月值分析, SW5 在 9 月达 III 类, 其它点位基本为 II 类. 部分监测点位 TP 监测数据接近 III 类, 也进一步说明入湖支流 (源 口水、沙田水及罗溪水等小流域范围) 存在的城镇化、工矿企业开发建设及农村生产活动对水体造成一定的 影响. 其它点位水质情况呈现由差逐渐变好的趋势, 主要与近年来流域实施的生态整治和污染治理有关, 包 括流域内退耕还林、关闭上游铇矿、分批取缔网箱养殖、迁移污染型企业等一系列饮用水源地治理与保护 措施.

\section{4 水生生物多样性变化趋势}

\section{1 浮游生物变化趋势}

柘林湖浮游生物目前尚没有进行长期系统的监测,2006 年 7 月和 2007 年 7 月,肖秀兰等 ${ }^{[16]}$ 对江西武宁 县柘林湖的浮游生物进行了初步调查, 结果表明: 柘林湖在 7 月份浮游植物生物量为 $66.88 \times 10^{-2} \mathrm{mg} / \mathrm{L}$, 浮 游动物生物量为 $1.33 \mathrm{mg} / \mathrm{L}$. 柘林湖浮游藻类组成以绿藻和硅藻为主, 柘林湖网箱养殖区内共检出浮游植物 6 门 23 属 23 种, 其中绿藻门 8 种, 占 34. 78\%. 浮游生物优势种为腔球藻 (Coelosphaerium sp.) 、微囊藻 ( Microcystis sp.) 、飞燕角甲藻 (Ceratium hirundinella) 、角星鼓藻 (Staurastrum sp.) 、螺形龟甲轮虫 (Keratella cochlearis)、桡足类的无节幼体、象鼻溞 (Bosmina sp.)、剑水蚤 (Cyclops sp.) 等.

2012-2013 年对 16 个监测点位进行为期一年的水生生物调查监测, 结果表明全湖藻类演替规律以蓝 藻一硅藻交替为主, 夏季湖区藻类主要以鱼腥藻 (Anabaena sp.) 和微囊藻为优势种, 冬季以直链藻 (Melosira sp. ) 小环藻 (Cyclotella sp.) 和针杆藻 (Synedra sp. ) 占优. 从浮游生物生物量及群落组成看, 在夏、秋季东渡 取水口浮游植物丰度较高, 达到 $10^{7}$ 数量级, 生物量为 $12.7 \mathrm{mg} / \mathrm{L}$; 浮游动物生物量较高的季节是夏季, 总量 达 $8.08 \mathrm{mg} / \mathrm{L}$; 其次是秋季, 为 $2.32 \mathrm{mg} / \mathrm{L}$; 最少的是冬季和春季, 为 $0.17 \mathrm{mg} / \mathrm{L}$. 从时空变化格局看, 在夏、秋 季污水处理厂排口、宋溪湾和东渡取水口发生了藻类水华现象, 主要为鱼腥藻 (夹杂着束丝藻 (Aphanizomenon sp. ) ) 水华, 其次为轻度微囊藻水华, 蓝藻优势度均在 $90 \%$ 以上, 仅占全湖水面面积的 $2.5 \%$. 浮游动物 中的耐污种如螺形龟甲轮虫大量出现, 成为优势种之一; 因此, 从历年趋势可知, 湖区的浮游植物类群从绿 藻门占优势演替为当前局部湖区蓝藻门占优势, 柘林湖局部湖区水生态安全有逐步退化的迹象.

\section{2 底栖生物变化趋势}

之前对柘林湖底栖生物没有开展相关研究, 2012-2013 年底栖监测结果表明清洁的采样点 10 个, 轻污 染的采样点 4 个, 中污染和重污染的采样点各 1 个, 分布在官莲湾和坝上. 人湖河口等采样点寡毛类密度较 低, 如巾口码头和罗坪河口均出现了 Wright 生物指数为 0 的结果, 表明采样点水质清洁. 库湾及坝上等采样 点寡毛类密度较高, 官莲湾和坝上采样点的 Wright 生物指数分别为 1855 和 6125 , 污染相对较重. 


\section{3 鱼类资源变化趋势}

柘林湖上游湿地是中华秋沙鸭 (Mergus squamatus) 越冬种群的栖息地,更发现有“水中大熊猫”之称的 桃花水母 (Craspedacusta sowerbyi). 1975 年柘林湖建成后, 水产部门对柘林湖进行过一次鱼类调查 ${ }^{[17]}$, 结果 显示柘林湖拥有鱼类 73 种,分属 9 目 23 科,以鲤形目鱼类最多,计 48 种,占 $65.8 \%$; 其次为鲈形目 10 种,占 $13.7 \%$; 鲇形目 5 种,占 $6.8 \%$; 鳗鲟目和鲑形目各 2 种,各占 $2.7 \%$; 领针鱼目、刺鲀目、鳢形目、合鳃目各 1 种, 各占 $1.4 \%$; 还有网箱养殖逃逸的斑点叉尾鮰 (Lctalurus punctatus) 和鲟 (Acipenser sp.) 等.

通过 2012 年度鱼类资源调查, 获悉近年来柘林湖湖区鱼类呈现小型化、低龄化、群落结构单一化的趋 势, 生物多样性降低, 非养殖性捕捞渔获量日趋减少, 平均渔获量从 $1990 \mathrm{~s}$ 的 $200 \mathrm{~kg} /(\mathrm{d}$ - 船) 降到目前的 20 $\mathrm{kg} /$ ( d - 船) 以下, 捕捞到的野杂鱼数量也明显减少, 部分以前常见的鱼类濒临绝迹, 虽然设置了常年、季节 性休渔区及休渔时间 (4-6月), 还设置了鱤鱼 (Elopichthys bambusa)、鳜鱼 (Siniperca sp.) 及银鱼 (Salanx sp. ) 保护区,但鱼类仍呈小型化、低龄化等趋势. 2012 年共收集和记录鱼类 50 种,分别隶属 7 目 14 科 38 属, 其中以鲤科鱼类为主,占总种数的 $58.0 \%$, 其次为鮨科 $8 \%$,魭科和鲇科各占 $6.0 \%$, 䱊科 $4.0 \%$, 鳀科、银 鱼科、鳗鲡科、鰕虎鱼科、太阳鱼科、合鳃鱼科和鳢科等各占 $2.0 \%$.

\section{4 水生植物变化趋势}

根据资料记载及实地的植物资源考察 ${ }^{[18]}$, 柘林湖流域天然湿地面积较小, 仅为 $136.09 \mathrm{~km}^{2}$, 大部分为人 工和河流湿地, 水生植被主要分布在武宁大桥以上修河流域范围, 以野生湿地植物为主, 共有野生湿地维管 植物 81 科 209 属 328 种. 受人为及自然条件影响, 柘林湖流域湿地功能呈退化趋势, 2012 年度调查共发现 柘林湖湖区范围内有水生 (湿生) 植物 18 科 25 属 30 种, 挺水植物和湿生植物中常见的有禾本科、水鳖科、 金鱼藻科、菱科、茨藻科和菊科等. 真性水生植物 16 种, 其中浮叶植物 5 种, 分别是莲 (Nelumbo sp. ) 、菱 (Trapa bispinosa)、细果野菱( Trapa maximowiczii)、冠菱( Trapa litwinowii)、格菱 (Trapa pseudoincisa)、田字萍 (Marsilea quadrifolia) 等; 漂浮植物 4 种, 分别是满江红 (Azoila imbricate)、凤眼莲(Eichhornia crassipes)、紫萍 (Spirodela polyrhiza) 和浮萍 (Lemna minor) ; 沉水植物 7 种, 分别是刺苦草 (Vallisneria spinulosa) 、细金鱼藻 (Ceratophyllum submersum) 、金鱼藻 (Ceratophyllum demersum)、狐尾藻 (Myriophyllum sp.)、大茨藻 ( Najas marina L. ) 、罗氏轮叶黑藻 (Hydrilla verticillata) 和马来眼子菜 (Potamogeton malaianus) ; 其他伴生种有禾本科五 节芒( Miscanthus floridulus)、糠稷 (Panicum bisulcatum Thunb.)、荻 (Miscanthus sacchariflorus)、狗牙根 (Cynodon dactylon), 合萌(Aeschynomene indica Linn. )、葛( Pueraria lobata), 狭叶香蒲( Typha angustifolia) 等.

\section{5 柘林湖水生生态环境变化驱动力分析}

纵观柘林湖近 30 年来的水生生态环境变化趋势, 水质总体从 I 类下降为 III 类, 湖区水生生物多样性呈 降低趋势. 经分析, 水环境质量主要限制性因子为 TP 和 TN, 其主要驱动力因子除与自然因素 (气温、水温、 光照、降雨量以及风速等) 有关外, 更受到人类活动因素 (人口数量、经济发展水平和污染物排放量) 的直接 影响 ${ }^{[19-20]}$.

\section{1 城镇化、工业化进程加快, 入湖污染负荷呈逐年增长趋势}

$1980 \mathrm{~s}$ 年, 流域内基本无大型工业, 水产养殖业也仅为天然放养模式, 2000 年以来, 随着城镇化、工业化 进程加快, 土地利用的格局和方式有所改变, 且随着流域人口数量及工业企业数量的增加, 流域总用水量和 工业用水量呈总体增加趋势, 工业、生活、农田灌溉等用水量大幅增加, 从 $2.56 \times 10^{8} \mathrm{~m}^{3}$ 增至 $5.63 \times 10^{8} \mathrm{~m}^{3}$, 增长达 2 倍, 同时对供水保证率的要求越来越高. 流域人均 GDP 在近 30 年内从 530 元/人增至 15378 元/ 人,翻了近 30 翻, 当地居民增收需求以及用水量的增加推动废水量及人湖污染负荷逐年增长.

\section{2 湖区非点源污染是影响水生生态环境的重要因素}

据调查,非点源由于输人途径和很多因素有关,特别是城镇径流和农业面源径流量与当年水文条件有 关, 畜禽养殖污染与养殖量有关, 负荷呈波动变化的趋势, 没有一定规律, 但近 30 年来非点源负荷总体呈增 大趋势. $1980 \mathrm{~s}$ 至 2013 年, TN 负荷从 $0.0001 \mathrm{t} /\left(\mathrm{hm}^{2} \cdot \mathrm{a}\right)$ 增加至 $0.0028 \mathrm{t} /\left(\mathrm{hm}^{2} \cdot \mathrm{a}\right)$, TP 负荷从 $0.00001 \mathrm{t} /$ $\left(\mathrm{hm}^{2} \cdot \mathrm{a}\right)$ 增加至 $0.0002 \mathrm{t} /\left(\mathrm{hm}^{2} \cdot \mathrm{a}\right)$.

非点源负荷中以水产养殖污染为人湖磷的主要来源,2000 年以来柘林湖曾大力发展网箱养殖活动,据 
水产部门统计, 共有 22000 余箱网箱, 345 座养鱼库湾, 柘林湖湖区网箱养殖面积共 $65.93 \mathrm{~km}^{2}$, 养殖面积占 湖区面积的 $20 \%$, 为了提高养殖水域的浮游生物产量, 大量投人化肥用于肥水, 养殖水体出现富营养化, 网 箱养殖污染系数按每公顷网箱养殖面积年产生 $\mathrm{COD}_{\mathrm{Cr}}$, TN 和 TP 分别为 74.5、101 和 $11 \mathrm{~kg}$ 计算 ${ }^{[21]}$, 则 $65.93 \mathrm{~km}^{2}$ 网箱养殖向柘林湖水体排放的 $\mathrm{COD}_{\mathrm{Cr}} 、 \mathrm{TN} 、 \mathrm{TP}$ 分别为 491. 19、665.89 和 72.53 t/a. 但近 3 年流域 内开始实施柘林湖生态环境保护工程, 网箱养殖逐渐取缔, 水产养殖直接人湖污染负荷呈先增加后减少的 趋势. 此外农村种植业流失源次之, 沿湖 100 多公里建设了很多农田, 湖区的农药用量以年均 $11.0 \%$ 的速度 增长, 而农药施用后 $10 \% \sim 20 \%$ 附着在植物体上, $80 \%$ ～90\% 散落在土壤和水体里. 流域历年化肥农药平均 施用量为 $367 \mathrm{~kg} / \mathrm{hm}^{2}$, 远高于 $280 \mathrm{~kg} / \mathrm{hm}^{2}$ 的生态乡镇标准, 是世界平均施用量的 1.8 倍, 而化肥利用率只有 $30 \% \sim 40 \%$, 其余 60\% 70\% 进人环境.

\section{3 近湖区农村生活污染负荷高,污染治理设施落后}

目前沿湖所在 3 县人口从 $1980 \mathrm{~s}$ 年的 105.95 万增加至 2013 年的 123.92 万 (图 2 ), 农村人口从 58.42 万增加至 105.07 万, 农村生活污水量也从 $1706.08 \times 10^{4} \mathrm{t} / \mathrm{a}$ 增至 $3235.89 \times 10^{4} \mathrm{t} / \mathrm{a}, \mathrm{TN}$ 和 TP 污染物人 湖量分别由 $371.65 、 17.81 \mathrm{t} / \mathrm{a}$ 增至 582.87、27.98 t/a; 在空间上, 滨湖乡镇较近的空间距离和较高的污染基 数与柘林湖非点源人湖负荷密切相关, 因此滨湖乡镇成为湖泊非点源污染的重点控制区. 虽然在当地财政 有限的财力下将 $80 \%$ 的资金投人在江河治理与生态保育中, 对修河、大田水、澧溪河等中小流域实施了一系 列江河治理工程和源头水源涵养林工程, 并在流域内加大了城镇污水处理厂、垃圾处理设施的建设力度, 但 治理速度赶不上污染速度, 农村环境基础设施建设仍然滞后, 几乎没有农村生活污水处理设施, 农村生活污 水直排附近受纳水体, 最终随地表径流进入柘林湖. 此外目前仅有 $10 \% \sim 20 \%$ 的自然村建有垃圾收集房以及 配有垃圾桶, 农民习惯于将生活垃圾倾倒在路边以及水体附近, 人湖水系沿岸成为主要垃圾堆放场所.

\section{4 滨湖区生态安全屏障受人为活动破坏,负荷削减能力减弱}

2000 年以来随着湖泊资源观光价值日益提升, 沿湖岸边人为侵占湖泊湿地资源问题严重, 如宾馆设施 (柘林湖宾馆、北戴河宾馆、清水山庄等)、居民楼及住宅小区沿湖而建等现象明显增加; 部分湖区因苦草和 菱分布面积较大, 周边居民大肆采集作为家禽家畜的饲料, 存在一定程度的无序利用现象, 导致部分湖区 (如武宁大桥旁) 生态安全屏障受到破坏, 进一步削弱了湖泊生态屏障对人湖污染源的阻隔效应. 此外作为 生态操控最好的鱼类资源也受到人为干扰, 栖息地和产卵场减少, 特别是过度捕捞导致主要经济鱼类资源 衰退, 在巨大经济利益的诱导下每年捕捞量不断增加, 捕捞渔具网目不断加密, 致使经济鱼类不断挤压野杂 鱼生态位, 野杂鱼数量趋于减少, 鱼类生物多样性降低, 鱼类群落结构小型化和低龄化趋势明显.

\section{6 结论}

在近几年的水质良好湖库生态环境保护实践过程中,我们发现湖泊流域是一个“经济一社会一水生生态” 复合系统, 湖库水生生态变化的驱动机理与影响因素比较复杂, 湖泊问题的准确识别需要大量数据监测、机 理研究及分析方法的全面支撑, 目前对良好湖库水生生态变化机制系统研究相对较少, 仅有抚仙湖、梁子 湖、千岛湖、太平湖、南四湖、邛海等良好湖泊在不同领域的相关研究 ${ }^{[22,24]}$, 大多数试点湖库因科学数据缺乏 和保护实践经验积累不足, 在保护方案制定方面不可避免地存在盲目性, 因此亟需优化配置湖体水生生态 监测点位及增加监测频率、加强对湖库流域长相间相关数据积累并辅以多元统计回归分析, 识别更多的驱 动因子贡献, 总结水质良好湖库水环境保护的成功经验, 为国家良好湖库保护的战略实施提供借鉴 ${ }^{[25]}$.

本文以柘林湖为例, 在掌握历史数据和基线调查的基础上分析得出, 柘林湖水生生态环境变化的驱动 力和胁迫因子主要是流域内日益增长的人口压力、经济增长、污染物排放量增大及不合理的资源开发等. 因 此要保护好柘林湖的水生生态环境, 应从整个柘林湖流域着手, 从影响湖库生态安全状况的“人口增长一产 业发展一资源利用一负荷控制一生态保护政策管理” 耦合作用过程出发, 处理好 “人湖” 关系, 尊重湖泊生态系 统的自然属性, 辅之采取科学合理的措施进行集成研究和综合防治, 增加污染负荷治理设施控制非点源污 染负荷输人, 对滨湖区实施退田 (楼) 还湿地, 加强对 13 大人湖支流实施生态缓冲带建设, 对人湖负荷实施 最后一道污染物拦截生态屏障 ${ }^{[26]}$, 实现从污染防治、生态保护、生态建设的 “三次飞跃” 和从区域管理到流 域管理、从单一管理到协同管理、从部门履职到人人参与、从例行监测到在线监控的管理模式的“四大转 
变”. 只有实现“人湖” 和谐 “三次飞跃” 和“四大转变”, 并建立长远的制度保障和机制支撑, 发挥其应有的 生态效应,才能行之有效地改善柘林湖水生生态环境, 从而保障鄱阳湖人湖“一湖清水” ${ }^{[27]}$.

\section{7 参考文献}

[ 1 ] 金相灿, 王圣瑞, 席海燕. 湖泊生态安全及其评估方法框架. 环境科学研究, 2012,25 (4) : 357-362.

[ 2 ] 姜加虎,王苏民. 长江流域水资源、灾害及水环境状况初步分析. 第四纪研究,2004,24(5):512-517.

[ 3 ] 郑丙辉,王丽靖,李 虹等. 湖库生态安全调控技术框架研究. 湖泊科学,2014,26(2) : 169-176.

[ 4 ] 吕忠梅,熊晓青. 环境法视野下的“良好湖泊优先保护”. 环境保护,2012,14:16-20.

[ 5 ] 王圣瑞. 鄱阳湖生态安全. 北京:科学出版社,2014:9-11.

[ 6 ] 江西省水利厅,江西省统计局. 江西省第一次水利普查公报. 江西水利科技,2013,(2):79-82.

[ 7 ] Lei LM, Wu YS, Gan NQ et al. An ELISA-like time-resolved fluorescence immunoassay for microcystin detection. Clinica Chimica Acta, 2004, 348: 177-180.

[ 8 ] 雷腊梅, 甘南琴, 张小明等. 三种检测微囊藻毒素的 ELISA 方法比较研究. 高技术通讯,2004,14(7):89-92.

[9] 周凤霞,陈剑虹. 淡水微型生物图谱. 北京: 北京工业出版社,2010.

[10］胡鸿钧,魏印心. 中国淡水藻类:系统分类及生态. 北京:科学出版社,2006.

[11] Menaughton SJ. Relationship among functional prosperities of California grassland. Nature, 1967, 216: 168-169.

[12］李友辉,董增川. 柘林水利枢纽社会、经济、生态环境影响综合评价. 人民长江, 2006,37 (4) : 13-15.

[13] 王丽靖,郑丙辉. 水库生态安全评估方法 ( I ): IROW 评估框架. 湖泊科学, 2010,22(2):169-175.

[14] 修水县、武宁县统计年鉴 $(2000 \sim 2013)$.

[15］九江市监测中心站. $2000 \sim 2013$ 年柘林湖水质状况报告.

[16] 肖秀兰,杨 春, 李 达等. 柘林湖浮游生物初步调查. 江西水产科技,2008,(3):22-24.

[17］中国水产科学研究院淡水渔业研究中心. 江西省武宁县庐山西海生态渔业发展规划 $(2013 ２ 020), 2013$.

[18］修水县、武宁县第二次湿地资源调查报告,2011.

[19] 高 伟,陈 岩,徐 敏等. 抚仙湖水质变化 (1980-2011 年) 趋势与驱动力分析. 湖泊科学,2013,25(5):635-642.

[20］孙金华,曹晓峰,黄 艺. 滇池水质时空特征及与流域人类活动的关系. 湖泊科学,2012,24(3):347-354.

[21] 陈洪波. 三峡库区水环境农业非点源污染综合评价与控制对策研究 [学位论文]. 北京: 中国环境科学研究 院,2006.

[22］李文杰.梁子湖流域土地利用变化对流域水环境的影响 [学位论文].武汉:华中师范大学,2009.

[23] 徐鹏,高 伟,周 丰等. 流域社会经济的水环境效应评估新方法及在南四湖的应用. 环境科学学报, 2013,33 (8) :2285-2295.

[24] 幸晓琬,雷 波,肖 杰等. 邛海水质变化趋势及保护对策研究. 四川环境,2013,32(5):77-82.

[25] 李恒鹏,朱广伟,陈伟民等. 中国东南丘陵山区水质良好水库现状与天目湖保护实践. 湖泊科学, 2013,25(6): $775-784$.

[26] 刘慧丽,冯明雷,熊 鹏等. 柘林湖非点源人湖负荷估算及对策研究. 安徽农业科学, 2013,41(4): 1670-1673.

[27] 吴舜泽,陈 岩. 强化流域保护体系建设推进良好水体保护-《《良好湖泊生态环境保护规划( $2011-2020$ 年)》 解读. 环境保护, $2013,11: 13-16$.

[28] 中国环境科学研究院. 湖泊生态环境保护系列技术指南之一——湖泊生态安全调查与评估技术指南, 2014 .

[29］朱松泉. 中国淡水鱼类检索. 南京: 江苏科学技术出版社,1995.

[30］孔琼菊,方国华,马秀峰. 柘林水库的生态服务功能与价值评估. 人民长江, 2008,39(6):85-87. 